\title{
Inaccuracies in the history of a well-known introduction: a case study of the Australian House Sparrow (Passer domesticus)
}

\author{
Samuel C. Andrew* and Simon C. Griffith
}

\begin{abstract}
Background: Modern ecosystems contain many invasive species as a result of the activity of acclimatisation societies that operated in the second half of the nineteenth century, and these species provide good opportunities for studying invasion biology. However, to gain insight into the ecological and genetic mechanisms that determine the rate of colonization and adaptation to new environments, we need a good understanding of the history of the introduced species, and a knowledge of the source population, timing, and number of individuals introduced is particularly important. However, any inaccuracies in the history of an introduction will affect subsequent assumptions and conclusions.
\end{abstract}

Methods: Focusing on a single well-known species, the House Sparrow (Passer domesticus), we have documented the introduction into Australia using primary sources (e.g. acclimatisation records and newspaper articles).

Results: Our revised history differs in a number of significant ways from previous accounts. Our evidence indicates that the House Sparrow was not solely introduced from source populations in England but also from Germany and most strikingly also from India - with the latter birds belonging to a different race. We also clarify the distinction between the number released and the number of founders, due to pre-release captive breeding programs, as well as identifying inaccuracies in a couple of well-cited sources with respect to the range expansion of the introduced populations.

Conclusions: Our work suggests that caution is required for those studying introductions using the key sources of historical information and ideally should review original sources of information to verify the accuracy of published accounts.

Keywords: Acclimatisation, Bottlenecks, Propagule size, Range expansion, Hybridisation

\section{Background}

Species that were deliberately introduced through the efforts of the acclimatisation societies in the late 1800 s have been used as a 'natural' experiment to provide insight into a range of questions in ecology (Duncan et al. 2003; Cassey et al. 2004), evolution (Johnston and Selander 1964; Sax et al. 2007; Moran and Alexander 2014), and population and conservation genetics (Briskie and Mackintosh 2004; Congdon and Briskie 2010). One

\footnotetext{
*Correspondence: samuel.andrew@students.mq.edu.au Department of Biological Sciences, Macquarie University, Sydney, NSW 2109, Australia
}

reason for the focus on these human-assisted introductions is that the temporal and spatial scale enables us to study competition and adaptation by organisms in very different environments (to the natural range) over an appropriate timescale. Another key reason is that there is a sense that there are good data available on important 'experimental' variables such as propagule size, the source of the founders, and the sites of introduction. Certainly for vertebrates, the existence of a few key texts that summarise the introductions by the acclimatisation societies such as the works by Long (1981) and Lever (1985, 1987, 2005), suggest great promise for studies of invasive biology, and they have been well used as key sources 
for example by Cassey et al. (2004), Sol et al. (2008) and Blackburn et al. (2009). However, whilst these summaries are potentially valuable sources and represent an impressive effort in summarising the introduction histories of hundreds of species across the world, there have been very few efforts to evaluate the quality of the data summarised in them, and there are some reasons to suspect that the numbers are not always entirely accurate.

Many of the data summarised in accounts of introduced species (e.g. Long 1981; Lever 1985, 1987, 1992, 2005) are derived from the records of acclimatisation societies themselves, and are potentially compromised by inadequate reporting by these societies. Certainly in Australia animals were being introduced by private individuals before the establishment of the acclimatisation societies, and indeed the main rationale given for founding the first acclimatisation society (in Victoria, in 1857) was to provide better support (politically, logistically and infrastructure) for the already ongoing attempts to introduce animals (Courcy 2003). A central role of the societies was to house arrivals for a period of acclimatisation before they were released, and for many species they were also bred in captivity before release (Jenkins 1977; Leishman 1997; Courcy 2003). Following the initial burst of enthusiasm from the late 1850s to mid-1860s the acclimatisation societies often became administratively dysfunctional and marred by in-fighting as the enthusiasm for acclimatisation quickly passed, and in Australia they morphed into the first Zoological Parks (Lever 1992; Dunlap 1997; Leishman 1997; Courcy 2003). As a result, the record keeping and the reports vary in quality across the different Australian acclimatisation societies and over the years (the history of the acclimatisation societies of South Australia, New South Wales, Tasmania, Queensland, and Victoria, is dealt with in detail elsewhere: Rolls 1969; Jenkins 1977; Lever 1992; Courcy 2003).

The principal cause for concern over the reliability of historical data is the inconsistencies in the numbers reported across different sources. This is nicely exemplified by the work that has examined the effects of propagule pressure on invasion success of passerine birds introduced to Australia, New Zealand and the United States (Blackburn et al. 2011a, 2013; Moulton et al. 2011, 2012a, b; Moulton and Cropper 2014). In their study, Moulton et al. (2012b) highlighted the discrepancies between four different key sources with respect to propagule size and used the four different estimates to model the effect of propagule pressure on the success of introductions. For example the total number of House Sparrows (Passer domesticus) reported to have been introduced into Australia by these four sources were 345 (Ryan 1906), 130 (Jenkins 1977), 65 (Balmford 1981) and an unknown number greater than 100 (Newsome and
Noble 1986). Similar differences were found across other species, although for the question addressed successful establishment versus propagule size-the results were relatively consistent using the variety of different data available for each species (Moulton et al. 2012b). Similar problems were encountered with records from New Zealand (Moulton et al. 2011), suggesting that there may be persistent problems with this kind of data. Moulton et al's work $(2011,2012 b)$ demonstrates how variable the well-cited key sources of information can be. A single species case study on the Yellowhammer (Emberiza citrinella) by Pipek et al. (2015) in New Zealand shows the value of using additional primary sources of information. The problems do not just relate to the number of animals released and are therefore not just restricted to questions regarding propagule size.

Introduced and invasive populations have long been the focus of molecular study and again, here an understanding of the source of introduced populations is particularly important in interpreting outcomes. For example, significant genetic differences in allele frequency and diversity of microsatellites were found between the introduced House Sparrow populations of Kenya and North America (Schrey et al. 2011). This population differentiation is thought to be due to Kenyan populations being founded by birds from the Middle East or India and not from Europe which was the source of the North American House Sparrows (Lever 1987, 2005), rather than population differentiation being a result of stochastic factors (Schrey et al. 2011, 2014).

The available histories that we have of the introduced populations around the world (e.g. Long 1981; Lever $1985,1987,2005)$ will remain important sources of information that will help us to understand a range of questions in invasive biology. However, it is important to develop an appreciation of any deficiencies in summaries such as these and the likely sources of those errors (Moulton et al. 2011, 2012b) because a more detailed investigation of introduction history can unearth valuable information (Moulton et al. 2010). To that end, we have researched the introduction of the House Sparrow to Australia. This species is a good target for such work because, as a highly commensal species, it has been reasonably well documented over the past 150 years in both the scientific literature and popular accounts and was also well covered in the news media from the time of introduction (with the recent digitisation of these archives making them readily accessible).

\section{Methods}

\section{Introduction and establishment records}

Our starting references were species accounts that described the introduction of the House Sparrow into 
Australia (Summers-Smith 1963; Anderson 2006; Higgins et al. 2006), and accounts of the introduction of birds into Australia (Long 1981; Lever 2005). We also searched all the volumes of the journal Emu (the long-running journal of ornithology for the Australian region) from 1901 to present using the key words of "sparrow", "house sparrow" and "Passer domesticus". From these starting references we followed up on all cross-referenced papers that appeared to be relevant to either the introduction, or the spread of the species. We also reviewed secondary sources of information in the form of journal articles and books that described the history of acclimatisation in Australia.

The inconsistencies that rapidly came to light in these secondary sources led us to review primary sources of information such as the annual proceedings of Australian acclimatisation societies; and the electronic archive of all Australian newspapers (Trove 2015) in an effort to establish details from contemporary sources from 1860 to the first decade of the twentieth century. We read through the annual proceedings of the Acclimatisation Society of New South Wales covering the key period 1864-1867, and the annual proceedings of the Zoological and Acclimatisation Society of Victoria from 1861 to 1875.

We conducted an online search of newspaper articles archived by the National Library of Australia using the Trove search engine (Trove 2015). We used the search term "sparrow" for all searches and refined our searches by selecting newspapers and dates to search within. We searched the Melbourne newspaper The Argus from 1855 to 1875 because there was discussion of the introduction for several years prior to the first shipments as the editor of this newspaper (Edward Wilson), was instrumental in the establishment of the acclimatisation movement in Australia. We searched other papers covering other regions for different periods as below and in line with the likely introduction timings for those places: Sydney Morning Herald, Tasmanian newspapers (including: The Cornwall Chronicle, The Mercury, Launceston Examiner), South Australia newspapers (including: Border Watch, The South Australian Advertiser, The South Australian Register, South Australian Weekly Chronicle) from 1860 to 1870, The Brisbane Courier, The Queenslander, Queensland Times, The Telegraph from 1863 to 1896, and The Barrier Miner (the local newspaper of Broken Hill, NSW) from 1860 to 1900 . We also searched Western Australia newspapers (including: The Beverley Times, The West Australian, Western Mail) from 1900 to 1980 to find more details on the unsuccessful arrivals of sparrows in Western Australia. The majority of flagged articles were linked to the surname 'Sparrow' or did not contain information relevant to the introduction and history of the House Sparrow in Australia. However, we found 67 newspaper articles (see Additional file 1: Table S1, PDF's of these articles have been uploaded to figshare at https:// dx.doi.org/10.6084/m9.figshare.2061150) that contained relevant information, not including reprints of the same story in other newspapers or articles that gave no new details. We have cited these newspaper articles (NA1) in the text by using the reference number given in Additional file 1: Table S1. Newspaper articles are ordered by date of publication and are cited in tables and Additional file 1: Tables S1, S2, S3, S4, S5 and S6 if not in the main text.

We also consulted the online Historical Atlas of Living Australia (HALA 2014) to identify the earliest records of House Sparrows observed in different local government regions of Australia (source of these entries is reported in Additional file 1: Table S4). The HALA collates records from a variety of sources such as museum specimens and government reports, and in this case the most valuable information we found through that route was a New South Wales Department of Agriculture report that summarised the results of a postal survey in 1905 that had been conducted between 1890 and 1905 to investigate the spread of the sparrow across the whole of NSW (Musson 1907). Using the HALA we also identified dates from bird surveys in Rockhampton, and Roma in Queensland and Tennant Creek in the Northern Territory. In addition to searching the HALA for arrival dates we used literature searches for bird lists published for regions with unknown arrival dates for the sparrow. In these cases the key terms were 'bird list' and the location name. For a number of towns (Innisfail, Mt Isa, Townsville, Atherton and Torres Strait) we found publications that specifically summarised the arrival of the species in the region (Additional file 1: Table S4).

The collection of primary evidence described above allowed us to characterise the spread of the House Sparrow across Australia. We often found unequivocal discussion in the newspaper articles of the arrival of the species in the location. Articles either reported the arrival of shipments of sparrows and details of the numbers and site of release, or in areas that were naturally colonised, such as Broken Hill, stories documented the incidence of sparrows on a certain date and made clear reference to the absence of them at an earlier time.

The information collected is not suitable for any quantitative analyses but is appropriate for description and visualisation through a map charting the temporal and spatial spread of the species across Australia, which can be usefully compared to earlier representations of the House Sparrow invasion (Summers-Smith 1963; Jones 1986). 


\section{Results}

We found that important details about the House Sparrow introduction to Australia as often reported in well recognized and widely cited secondary sources (see Table 1 for Summary), are inaccurate. There are inconsistencies between these secondary sources and also between those and the information we constructed from primary sources (Table 1). For example, the total number of House Sparrows liberated in Melbourne varies widely between all sources, from as few as 65 to over 400 . Whilst is it widely accepted that the introduced birds were from England (all secondary sources in Table 1), we found strong evidence that the first House Sparrows to breed in Australia were from India, with good indications that House Sparrows also came from other sources in Europe. Below we summarise the new details and clarify contradicting reports (Table 2 provides our revised summary). We have structured our findings by considering the different states/territories involved separately as at the time of the introduction (over 40 years before federation) these entities were economically and politically very isolated. Furthermore, from the perspective of a sparrow they were biologically isolated with vast tracts of inhospitable habitat separating the major settlements of these colonies and the immediately adjacent farmlands.

\section{The initial introduction into Victoria}

Most sources report that the first successful arrival of House Sparrows to Melbourne was on the Princess Royal in January 1863 (19 birds), followed by another shipment in June of the same year (see Table 2 for more details on all introductions). We confirm that House Sparrows were amongst the birds landed from the Princess Royal on 26 January 1863, but we have found clear evidence of House Sparrows already being in Australia before that. A newspaper article from 29 November 1862 reported a private shipment by a Mr. Landells, of a number of animals including 11 'Indian Sparrows' (NA 4). These were confirmed to be $P$. domesticus in another newspaper article that documented the grateful receipt of "four Indian house sparrows, from Mr. G. J. Landells" by the Acclimatisation Society of Victoria in December 1862 (NA 5). On 23 January 1863, another newspaper article (NA 8) reported on the breeding success of the earlier shipment of sparrows (that are presumably the Indian ones) in the aviary in Melbourne, before the Princess Royal shipment arrived. This article (from 23 January 1863 NA 8) leaves no room for doubt that these 'Indian sparrows' are $P$. domesticus, "Perhaps the most important inhabitants of this locality are the sparrows, about which there can be no mistake. They are the cock-sparrow of English city tradition or nothing, nor have they sacrificed a single characteristic to their change of country. Their impudence in inimitable, and their strut and inquisitive cocking of the head and impertinent twist of the tail, are as familiar to them as ever..., ... and few will regret their appearance on the roofs and on the streets of our city and suburbs. This may be looked for, for they are breeding fast." This article therefore confirms that the House Sparrow was already present and breeding before the arrival of the Princess Royal. On 31 January 1863, a report in The Argus (NA 10) refers to the sparrows that have recently arrived on the Princess Royal, but also makes it quite clear again that there are sparrows from earlier imports and that they are breeding: "The young sparrows, born of the older importations, have tumbled out of their nest, and will soon set up for themselves, while other sparrows and linnets are again breeding, probably for the last time this season." We did not find any earlier mention of House Sparrows being brought in before 1862 and therefore suggest that the species arrived into Australia in 1862 initially from India. In September 1863 a female House Sparrow arrived in Ballarat (brought over from Europe by a Mr. Weber) as the sole survivor of a flock of 160 that were originally taken from Germany (NA 22). Therefore, in the space of less than a year House Sparrows were documented as arriving in Australia from source populations in India, England and Germany.

Whilst we were unable to find confirmation of their eventual arrival there are also reports of plans to ship sparrows from Ceylon (NA 14 Argus 30 April 1863), and Vienna (NA 37 The Mercury 19 June 1866). In March 1863 the ship 'Adam Sedgewick' left Calcutta, with more sparrows on board (from India) (NA 15), and two of these were recorded as landing and were confirmed as being from India (NA 17) whilst the ship 'Relief' arrived in July 1863 with an unspecified quantity of 'London sparrows' on board (NA 16), which were taken to an aviary in Pentridge where they were reported to be pairing well (NA 19). So House Sparrows were arriving from England as well as other being sent from other source populations.

The diversity of sources from which the House Sparrow was sent reflects its wide distribution at that time and the commercial nature of the acclimatisation operation. An article posted by the Acclimatisation Society of New South Wales, in the Sydney Morning Herald (NA 11), suggests that if people place their orders, Mr. Landells will ship more Indian House Sparrows at ten shillings each, presumably under-cutting the cost of shipping them from England. Shipments of the species from India were also more likely to survive the shorter voyage than those from Europe (it is apparent from the primary sources that the majority of House Sparrows loaded in Europe failed to survive the long sea journey from there to Australia. See Table 2 and Additional file 1: Table S2 for details). 


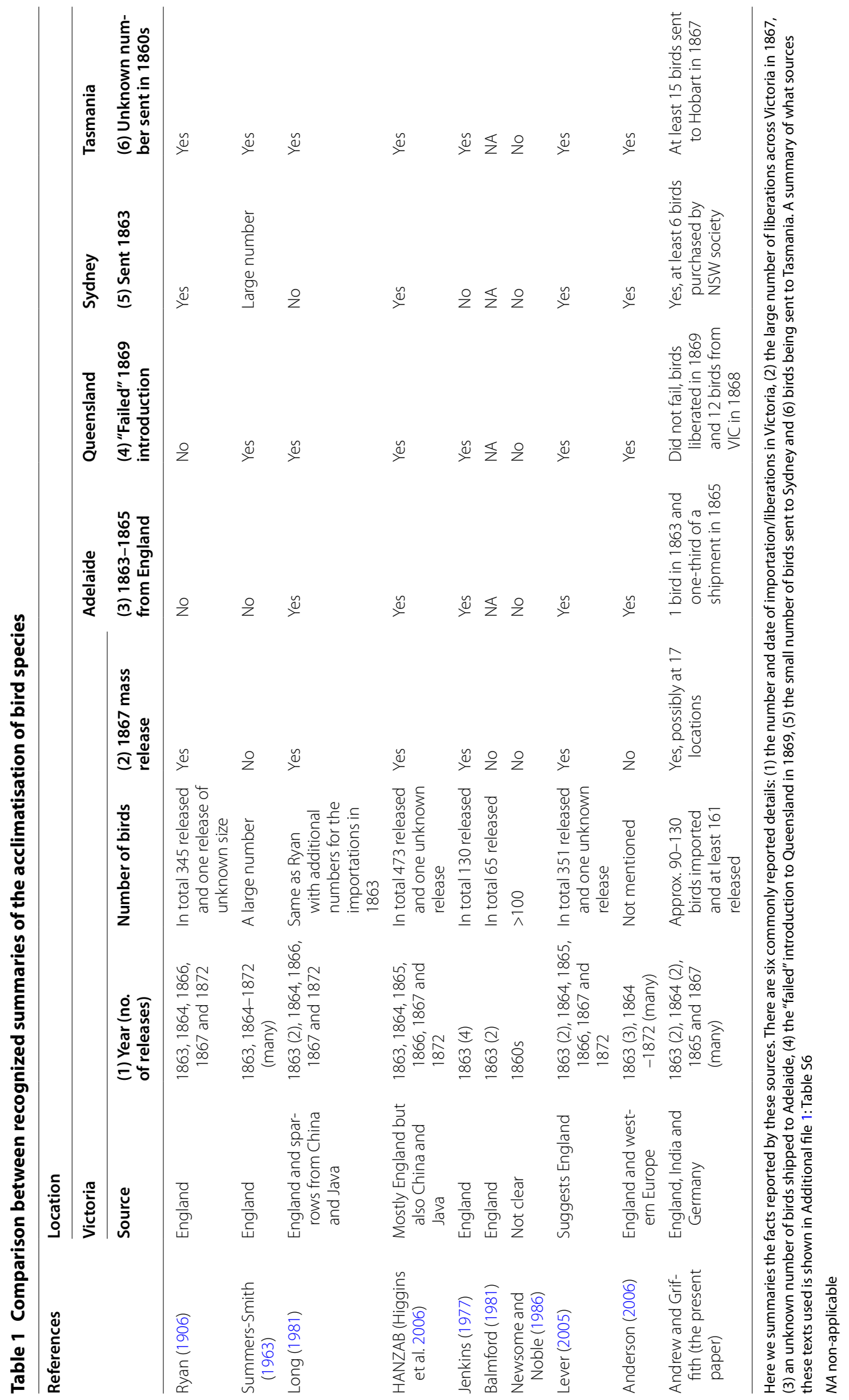




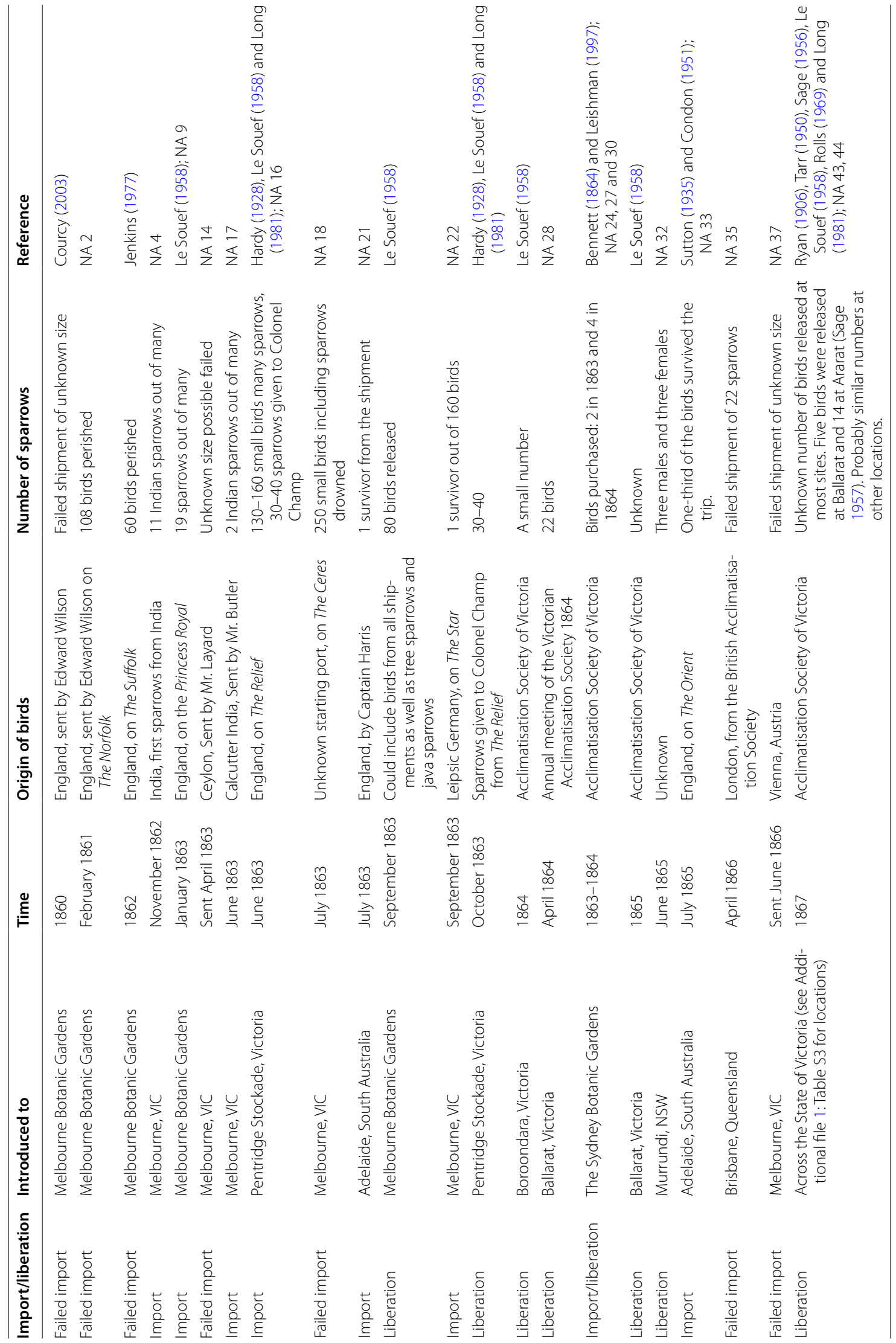




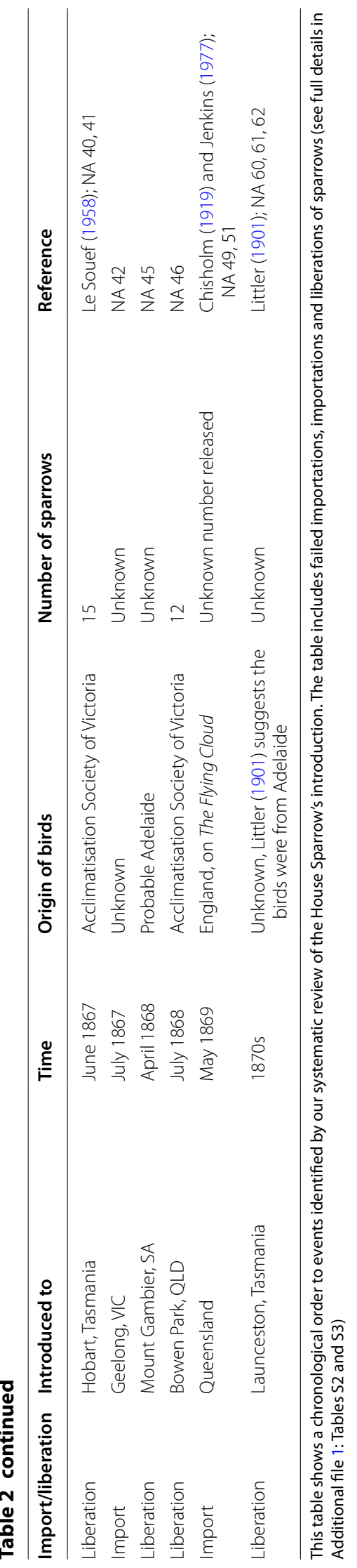


From our reading of the primary sources, we believe that the main effort to import the House Sparrow was concentrated in the years between 1862 and 1867, and that during that period the shipments that did arrive were probably still sufficiently newsworthy to have been covered. Certainly there are multiple articles documenting many of the arrivals of birds (suggesting that multiple papers felt them important enough to cover). Given how quickly the birds appear to have increased in number in Melbourne (see below), we suspect that there were no further significant imports after about 1869 given the difficulty of shipping them and the increasing consternation about the potential for them to become a pest. All of the arrivals by ship that are documented in the newspapers are listed in Additional file 1: Table S2. It remains diffcult to judge how well this represents the actual number of House Sparrows imported from overseas, and news coverage may have declined over time and some shipments may have been missed. Therefore, unfortunately, whilst the primary sources provide important insight into the multiple source populations from which the House Sparrow arrived in Australia, it is difficult to confidently chart the growth of the population of House Sparrows in the first few years, or work out what proportion of adults introduced in the these first few years came from different sources.

From our reading of the primary and secondary sources reporting on the imports and releases of this species it appears that the sources of some of the later inaccuracies are due to a confusion between imports and releases. Ryan (1906) reported that "120 were first liberated in the Botanical Gardens in 1863; in 1864, 125 more; in 1866 another lot, and in 1867, many birds about Melbourne were caught and were distributed generally over the state of Victoria, and in 1872, 100 more were imported and liberated.". In the first coherent attempt to characterise the species' introduction into Australia, Sage (1957) reported the same numbers by Ryan (but does not cite Ryan). These records (which form the basis of many of the more recent estimates of the propagule size of the House Sparrow in Australia) are problematic for a few reasons. First we are unable to identify all the birds liberated in 1864, and we only have records for a small number released in Boroondara (Le Souef 1958). Alternatively, the 1864 liberations could refer to shipments sent in 1863 but for which we cannot find any further details of arrival (Table 2). The 1866 liberation could refer to a shipment of 100 birds sent from Vienna to Melbourne (NA 37) but we have no record of these birds successfully arriving. The 1872 shipment seems altogether unlikely. It is not mentioned in any newspaper article nor recorded in the 1872 or 1873 annual proceedings of the Zoological and Acclimatisation Society of Victoria. It could have been a private shipment; however it does seem unlikely that a private individual would have gone to the trouble and expense of importing new birds at this time given that House Sparrows were already abundant around the Victorian colony by this time (Additional file 1: Table S5).

Whilst these numbers reported by Ryan (1906) and Sage (1957) are typically interpreted as being the size of the population of House Sparrows imported and released, in fact Ryan (1906) just refers to the size of the release. On arrival into Melbourne, many, if not all, of the birds were established in aviaries managed by the Acclimatisation Society of Victoria before being later liberated locally in Victoria, or shipped elsewhere in Australia. There are no quantitative accounts of the number of birds breeding or the number of offspring produced in Australia in the first few years (either in aviaries or in the wild after release). There is also an absence of any records regarding escaped birds from captivity. We know that on arrival from the ships birds were taken to the aviaries, in which the House Sparrows were reported as breeding successfully and producing several broods in a season (NA 8,10). It is therefore likely that a good number of the birds documented as being released were hatched in Australia and may have come from a much smaller group of breeding adults. In total we have found evidence for approximately $90-130$ adults arriving on ships into Victoria, and suggest that the propagule size (and genetic bottleneck) is around 110 individuals because it seems likely that not every individual would have survived and produced offspring.

The 1872 annual proceedings of the Zoological and Acclimatisation Society of Victoria purportedly have a full list of all the animals imported and liberated by the society prior to 1872 (Black 1872). The records suggest that a total of 105 English sparrows (60 in Royal Park, 40 in Pentridge, and 5 in Ballarat), were released by the society before 1872 in the Melbourne area. However, the 1873 proceedings that we accessed and were cited by Balmford (1981) only report 65 sparrows being liberated, because a liberation in Pentridge Stockade was not included. Thus, the inconsistencies in the records appear to start very early on, with the 1872 summary being inconsistent with the $1873-1875$ proceedings. It is unlikely that the society released birds in the Melbourne area after 1872 because the species was already very well established in Victoria by this point, with newspapers from as early as 1868 suggesting that there were already hundreds of sparrows in the city (NA 47). By the early 1870s the policy of the Acclimatisation Society was also changing having realised they were introducing a species that was fast being recognised as a pest in Australia (Le Souef 1958; Higgins et al. 2006). For example, in 1875 they rejected a request to send House Sparrows to the 
Torres Strait for liberation (Le Souef 1958). With respect to the number of individuals that were initially brought into Australia from overseas, it is very difficult to come up with an accurate figure.

\section{Introduction into South Australia}

The first shipment to Adelaide in 1863 of 100 birds had only one surviving sparrow, which was sold at auction as the "only one in the colony" of South Australia in July 1863 (NA 21). The next documented landing of sparrows into Adelaide from England on The Orient (in July 1865) reported that one-third of the birds survived but the starting number was not reported (NA 33). These birds were delivered into captivity and there are later reports of sparrows being liberated in both Adelaide (NA 50), and Mount Gambier (NA 45). There is relatively little in the newspapers about further shipments or releases into South Australia, although we know that they were numerous in Adelaide by 1881 (Condon 1951). There is no evidence that birds were shipped from Victoria into South Australia and it is possible that the South Australian birds represent a separate and genetically independent source population.

\section{Introduction into Queensland}

In 1866, a report on a meeting of the Queensland Acclimatisation Society, confirms the loading of 22 sparrows onto a ship as a gift from the British Acclimatisation Society (NA 35); however there is no record of the arrival of these sparrows. The failure of these birds to have arrived is suggested by the observation that in a report on a meeting of the Queensland Acclimatisation Society in July 1868, 12 sparrows were recorded as having been sent up as a donation from the Acclimatisation Society of Victoria, and released (NA 46), and were still doing well and breeding the following year in February 1869 (NA 48). In April of 1869 a successful shipment of sparrows and other 'English birds' arrived on The Flying Cloud (into Brisbane from London), although unfortunately there is no detail of the number of arrivals beyond the fact that the numbers had been 'greatly reduced on the voyage' (NA 49, 51). These birds were released into the Botanic Gardens after they had recovered from the voyage (NA 51). In his summaries Chisholm $(1919,1926)$ maintains that this early introduction failed and that Brisbane and Queensland must have been populated by the natural spread of birds from the south in the early 1900s. For example Chisholm (1926) writes "While on a visit to Toowoomba in 1903 I noticed a small flock of about a dozen sparrows in the town and was told that only a few weeks before they had been seen for the first time". The picture presented by Chisholm $(1919,1926)$ was, not surprisingly cited and followed by Summers-Smith
(1963), and Jones (1986), which is not surprising because it seems to be so clear. However, it is clear from a number of newspaper articles dating from the 1870s and 1880s that the House Sparrow was thriving in both Brisbane and Toowoomba (NA 56, 57, 58), and there is very little doubt that Chisholm $(1919,1926)$ was wrong. It is possible but fairly unlikely that a species like the House Sparrow could have died out after being described as being so common in Brisbane that it had become a 'grievous evil' in 1881 (NA 57), to be absent for several decades before being replaced by later arrivals spreading from the south.

\section{Introduction into New South Wales}

In April 1864 the Acclimatisation Society of New South Wales reported that two sparrows had been brought into NSW in the previous year (NA 27), but there were no details as to where these came from, although Le Souef (1958) reports these as a gift from the Acclimatisation Society of Victoria. In November 1863, in another report covered by a newspaper, the Acclimatisation Society of New South Wales reported that the pair of sparrows (presumably in captivity in the Sydney Botanic Gardens) had laid eggs and that the female was incubating them (NA 24). A report on 3 December 1864 (NA 29) states that another five English sparrows were added to the collection in the aviaries in the Botanic Gardens in November 1864 (but again no hint of their origin). A second report (NA 30) on 6 December 1864 refers to the purchase of two pairs of English sparrows but unfortunately there are no details on where they came from or when exactly they arrived and given the date they could be included in the five new additions reported in the same week (NA 29). These are the only details that we have on sparrows being brought to Sydney, so it is very difficult to know where they came from. The only evidence of the introduction of sparrows into the wild is made in the fourth annual report of the Acclimatisation Society of New South Wales (April 1865) where it is stated that four English sparrows were liberated in Sydney (Bennett 1872) and apparently in the Botanic Gardens and Elizabeth bay a few kilometres away (Leishman 1997). The number of sparrows received and held by the Acclimatisation Society of New South Wales remained low compared to the operation in Melbourne and in the sixth report (1867) they refer to just three sparrows being kept in their collection in the aviaries. There are only two other records of sparrows being released in NSW. In 1865 in a communication to the Acclimatisation Society of New South Wales a Dr. Gordon of Murrurundi (in the Upper Hunter Valley) reported releasing three pairs of English sparrows in March of 1865. It is not clear where these birds came from but the nature of his letter makes it clear that they did not come from the Acclimatisation 


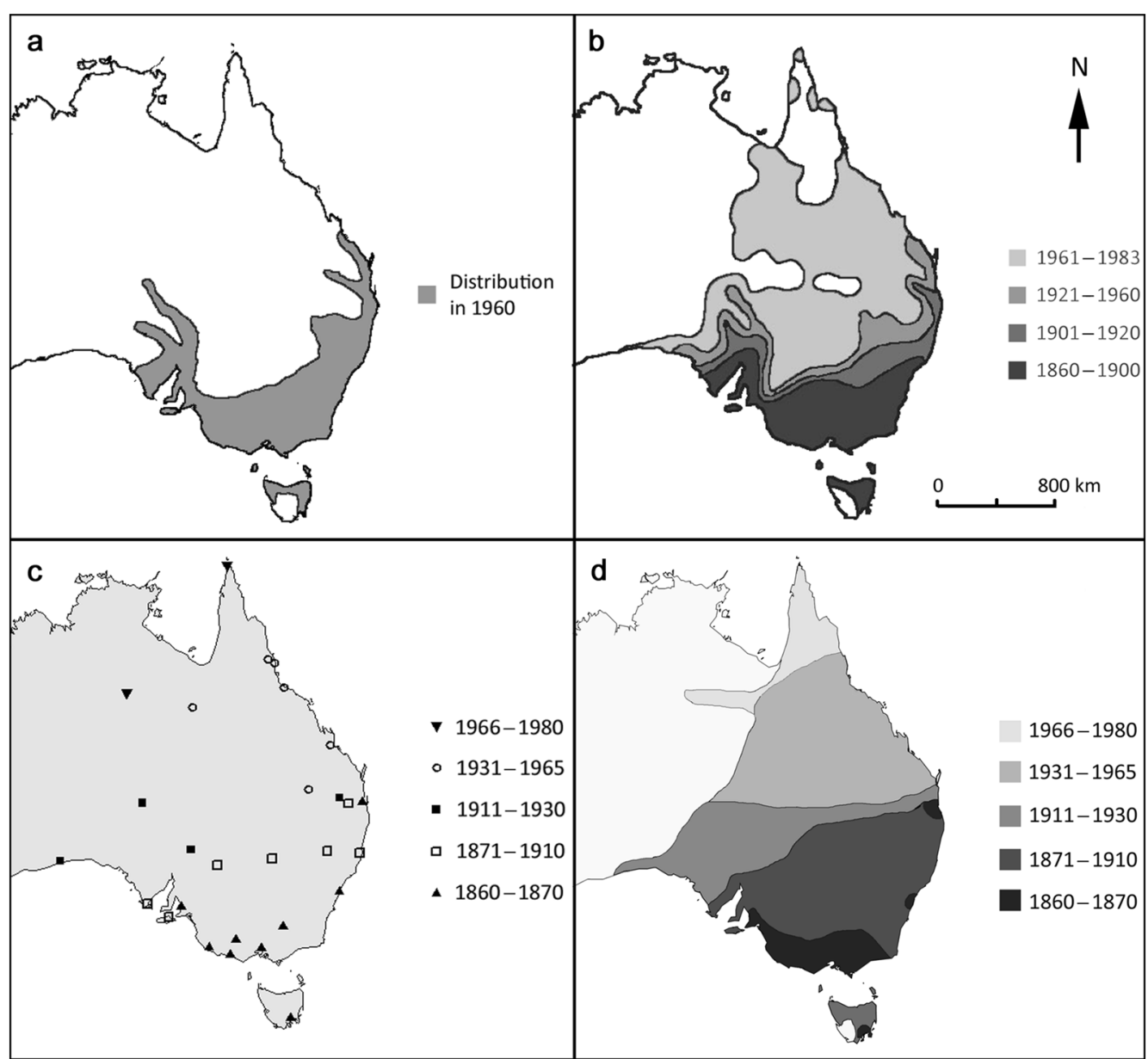

Fig. 1 The range expansion of the Australian House Sparrow. The map (a) is a redrawing of a distribution map published by Summers-Smith (1963) which estimated the distribution of Australian House Sparrows in 1960. The map (b) is a redrawing of a map by Jones (1986) which uses multiple sources of information to estimate the distribution of the House Sparrow in Australia at different time points and displays the range growth using contour lines. Jones' 1960 distribution line seems to follow Summers-Smith's distribution. The map (c) was generated from our research which collected the arrival time of House Sparrows in different towns and cities (see Additional file 1: Table S4 for full details). The map (d) uses our arrival points to draw our own contour lines which estimate the species range expansion between different time intervals in a comparable way to Jones (1986)

Society of NSW (NA 32). This letter suggests that individuals such as Dr. Gordon were acting independently to acquire and release sparrows. Dr. Gordon could have either imported them into Australia from overseas, or perhaps acquired them from Victoria where they were already quite numerous by this time. The other mention of an introduction is in a newspaper article from 1881 (NA 55) discussing the issue of the sparrow as an agricultural pest. In this there is a report that sparrows were introduced into Parramatta in 1875. As Parramatta is just $20 \mathrm{~km}$ from Sydney it is most likely that these birds either arrived on their own or were moved from the established population in Sydney. The sparrow was starting to become common in other parts of Sydney by around 1875 (Rolls 1969; Leishman 1997).

\section{Introduction to Tasmania}

The Victorian Acclimatization Society sent 15 birds to Hobart in 1867 and these birds were reportedly going to be housed over winter before release (reported in June NA 41), but we could find no further mention of them in the newspapers. It was later reported that House Sparrows were taken from Adelaide to Launceston in the 1860s or 1870s (Littler 1901). A newspaper article from 1891 (NA 61) also suggests that the House Sparrow was introduced into Launceston 'about 20 years ago' by a Mr. 
Bennett from Launceston, with a slightly later article blaming the 'late Mr. Henry Bennell' (from Launceston, NA 62), so there is some disagreement over the spelling of the surname. Neither of these later articles gives any hint as to where they came from, although Adelaide, Melbourne and Hobart are the most likely sources and sparrows were doing well in both of these mainland colonies by the late 1860 s.

\section{Population establishment, range expansion, and current distribution}

In 1906 the President's Address for the Australasian Ornithologist's Union reviewed the successful introduction of a number of introduced European bird species, identifying the House Sparrow and Starling (Sturnus vulgaris) as the most successful invaders (Ryan 1906). By the early part of the twentieth century the House Sparrow was known to have spread across New South Wales, the south-eastern part of South Australia, all over Victoria, all of the human occupied areas of Tasmania, and some of the southern towns in Queensland (Ryan 1906; Musson 1907). As they spread into new towns, newly established populations of House Sparrows quickly grew to be described as in plague proportions over the first 10-20 years (see examples in Additional file 1: Table S5), demonstrating their capacity for rapid population growth and establishment success.

A distribution map of the Australian House Sparrow indicating the spread of the species over time, was produced in the monograph of the species by Summers-Smith (1963) describing the distribution in 1960 (Fig. 1a). Summers-Smith's (1963) distribution was not significantly different to Ryan's (1906) description of the distribution, which is a little surprising since they were separated by over 50 years. Jones (1986) produced an updated version of the temporal spread of the species, which is largely based on Summers-Smith's (1963) figure with additional range expansion points for after 1960 (Fig. 1b). In our review of the primary and secondary material available, we identified inaccuracies in both of these earlier accounts of the range spread (SummersSmith 1963; Jones 1986). Using arrival estimates for key towns across Australia (Fig. 1c; Additional file 1: Table S4) we produced a revised range expansion map for the House Sparrow in Australia (Fig. 1d). Our re-examination reveals a more extensive and quicker invasion across the southern states, as well as a quicker arrival in northern Queensland, with a more even rate of expansion overall (see Fig. 1 for comparison).

The House Sparrow was never intentionally introduced to either the Northern Territory or Western Australia. However the species has apparently made it by boat to Perth on many occasions before being detected and exterminated by the Department of Agriculture (Long 1988). Some of these arrivals were by a single individual and others were small groups with up to 10 individuals. The species has also expanded over land towards Western Australia across the South Australian border, and the earliest of these events was in 1914 (Long 1981) and also 1918 (NA 64). None of these range expansions have successfully breached the inhospitable Nullabour plain to reach the human settled areas of Western Australia. This failure is possible due to a consistent effort to eradicate expanding House Sparrows and other invasive species by the Western Australian Government (see examples NA 65, 66). In total Long (1988) found records for approximately 130 sparrows arriving in the docks of Perth or crossing the Western Australia border before extermination. A newspaper article from May 1969 (NA 67) linked the arrival of five sparrows in Perth to a boat that travelled directly from Lisbon, Portugal to Perth. This is an impressive distance for sparrows to hitch-hike by boat and suggests the possibility that sparrows could be continuing to enter Australia by boat from many countries and subsequently joining the already established populations in other cities (into which international freighters from around the world arrive).

The invasion of the Northern Territory by the House Sparrow has also been largely blocked by the harshness and scale of the arid habitat between the edges of the species range in South Australia to the south and Queensland to the east. The exception here is the small town of Tennant Creek, NT which is one of the last towns successfully invaded. The House Sparrow arrived in Tennant Creek in 1978 and we spoke to an eye witness who reported that they arrived from the east and had been colonising (in a stepping-stone process) the remote homesteads of cattle stations that are spread thinly from Camoweal in Queensland to Tennant Creek in the few years immediately prior to 1978 . Whilst the major towns and cities of the Northern Territory (Katherine, Darwin and Alice Springs) are all likely to provide suitable habitat for the House Sparrow, dispersal to those from Tennant Creek remains blocked by vast stretches of desert with an extremely low density of human homesteads, most of which are not likely to support a viable population of House Sparrows.

Between 1977 and 1981 the distribution of the House Sparrow was recorded systematically across Australia as part of the effort to create the first Atlas of Australian Birds (Blakers et al. 1984). The New Atlas of Australian Birds was produced 20 years later and there were no significant changes in the recorded distribution of the House Sparrow (Barrett et al. 2003). This suggests again that the expansion of the House Sparrow has been stable since the late 1970s (see Fig. 1d for map). 


\section{Discussion}

In conducting an intensive study of the history of the introduction of the House Sparrow into Australia, we discovered some very significant discrepancies with other well-used accounts. Both the source population and the number of individuals introduced appear to differ from the established record for this species. House Sparrows arrived in Australia from England, Germany and India, not just England. From a genetic viewpoint this is particularly important as those populations are genetically distinct and the Indian population is even a different race $(P . d$. indicus). The number of individuals introduced appears to have been much lower than previous estimates although we acknowledge that even our extensive historical research makes it difficult to ascertain an accurate number. Whilst these findings are of most interest to further work focused on this single species (e.g. Liebl et al. 2015), the discrepancies have broader implications with respect to the general accuracy of the well-cited references that are so well-used in invasive biology research.

The history of an introduced species provides an important foundation to a range of research questions relating to invasive biology (Duncan et al. 2003; Blackburn et al. 2011b) and population genetics (Dlugosch and Parker 2008). Much work in invasion biology has been based on the information provided by key references such as the books by Lever $(1987,2005)$ and Long $(1981)$, that provide a wealth of data on hundreds of introductions across the world. However, the quality of analyses and conclusions based on these and similar sources may be jeopardised by any widespread inaccuracies in these sources. The introduction of the House Sparrow to Australia has provided a good opportunity to evaluate the accuracy of secondary sources on a single introduction and in many areas we find that both in the 'introduction literature' and 'species accounts' many important details that have become well-established were wrong. Our findings, certainly cast some doubt on the quality of these general sources, and suggest that caution needs to be applied to future work using data derived directly from them. The errors we have identified are very significant biologically. For example, the genetic composition of the Australian House Sparrow population today is likely to reflect the admixture of three genetically distinct populations and it is interesting to note that even an early study with allozymes (Parkin and Cole 1985) identified a higher level of gene diversity in House Sparrows in Australia versus New Zealand (where sparrows were only introduced directly from a single source-England). Furthermore, there is a key difference in a propagule size of approximately 110 against 400 (the number reported by some sources), although again the situation is undoubtedly complicated. Around 400 individuals may have been released into the wild around Melbourne so the ecologically relevant propagule may be around 400 . However, if the majority of those 400 individuals were the progeny of a far smaller number of adults breeding in captivity, then the bottleneck and genetic propagule size are much smaller. This relatively subtle difference will be important depending on what particular question is being addressed.

We are reasonably confident that our revised history is accurate. It is unlikely that many song birds were successfully introduced into Australia prior to 1860 (Hardy 1928). Edward Wilson argued for the establishment of the first acclimatisation society in Australia because of the difficulties in keeping song birds alive on the long sea voyage (Courcy 2003). Perhaps because of Wilson's great interest in acclimatisation and his position as editor of one of Australia's key newspapers of the time (The Melbourne Argus), the local Australian newspapers in the 1860s-1870s regularly reported the activities of acclimatisation groups (see examples in Additional file 1: Table S1), and certainly seem to have covered all of the details that are covered by the proceedings of the societies themselves and the details that were picked up in other accounts of introductions. Importantly however, the newspapers go beyond these other sources and have provided significant missing details. The Australian newspapers therefore appear to be a very useful source, certainly with respect to the House Sparrow. It is possible that the coverage of other species would have been a little less thorough. The House Sparrow is a bird that people are very familiar with and it was newsworthy firstly because they were welcomed as an agent of biocontrol (to remove herbivorous insects on crops), and secondly as a familiar bird from home. Finally, within relatively few years the sparrow was being recognised as a pest and a number of newspaper articles focus on the debate about its status as a pest and efforts to eradicate it. The other key attribute of the sparrow is that they are a highly commensal species and they readily associate with people (SummersSmith 1963; Anderson 2006), therefore they would have been very recognisable and an obvious member of the avifauna. Therefore as sparrows arrived in new locations, their presence was very quickly noticed and noted in newspapers.

It has been suggested that some bird species were arriving in undocumented private shipments (Balmford 1981), but there is no indication that sparrows were present in areas before the introductions and arrivals that we have documented here, and again they are a species that seems to attract comment when they are around. The birds that were introduced presumably found urban and rural settlements that were perfectly suited to them and multiplied fast. Within just a few years of initial introduction 
(by 1870) there was an abundance of House Sparrows in the country (Additional file 1: Table S5), and it seems unlikely that people would have gone to great efforts to ship them from elsewhere in the world after this time (when they were still very much in the news). However it is certainly likely that small numbers would have arrived by hitch-hiking on ships as seems to have been the case in Perth, where they were detectable for the next century because of the ongoing effort to keep Western Australia sparrow-free (Long 1988; NA 67).

There are a number of reasons why the general sources such as the accounts by Lever $(1987,2005)$ and Long (1981) are erroneous on certain points. Perhaps a key one of these is that those sources are over-reliant on the records of the acclimatisation societies. Certainly in Australia the period from around 1860-1875 was the high point of the acclimatisation movement. After this period the societies started to decline, struggled to find funds and become administratively dysfunctional. The proceedings from the Acclimatisation Society of Victoria (which were the best of all of them) declined in quantity and quality over time and from 1872 to 1875 details were already starting to be lost when compared to the notes of earlier proceedings used by Le Souef (1958). Through old newspaper articles we have found many transcripts of regular meetings of acclimatisation societies that report details about correspondence with members of the society that was not being thoroughly minuted in the societies own records and provide important insight (Additional file 1: Table S1). The references given as source evidence also indicate that many of the authors of summary information for this species have failed to use all of the available sources (shown by limited references, Additional file 1: Table S6). There are also clear cases of incorrect interpretation and mis-citing of references in these texts that compound errors over time. For example Ryan (1906) reports 125 birds were liberated in 1864 (and he is referring to the total of releases across Victoria). Le Souef (1958) reports a small release of an unknown number of sparrows at Boroondara in 1864. Lever (2005) apparently puts the two together and reports 125 birds being liberated at Boroondara, Victoria in 1864, although we are unable to find any independent record of that number being released at that location. This is just one example of how different authors have published contradictory facts. The problem here is that a later author might now think that if 125 birds were released at Boroondara in 1864 then any birds released elsewhere in that year must have been additional ones which is not in fact the case, and thus the numbers get revised upwards.

Another possible source of confusion that arises from the proceedings of the Victorian Acclimatisation Society is that they also released 255 Java sparrows and 20
Chinese sparrows. These were not House Sparrows from Java and China as suggested by Hardy (1928) who is later referenced in HANZAB (Higgins et al. 2006). The former were Java Sparrows (Lonchura oryzivora), and the latter were Tree Sparrows (P. montanus, Le Souef 1958) that are the commensal sparrow in China. The Tree Sparrow is still found in Victoria and southern New South Wales to the west of the Great Dividing Range (Barrett et al. 2003), while the introduction of the Java Sparrow failed completely (Higgins et al. 2006). The adaptability and resilience of the House Sparrow is shown by its success on arrival compared to other failed introductions such as the Java Sparrow, Hedge Sparrow (Prunella modularis) and the Chaffinch (Fringilla coelebs). These differences likely relate to the ecology evolutionary potential of species to adapt to new environments (Cassey et al. 2004; Whitney and Gabler 2008). The House Sparrow did not really have to adapt to a new environment so much because they live in heavily modified urban and agrarian habitats, and had been associating closely with humans for 10,000 years (Anderson 2006). The environment available to the sparrow around Melbourne, Adelaide and Sydney in the 1860s was very similar to the one that they left in England, Germany and India. Food sources would have been primarily associated with horses, chickens and pigs and they would have nested in cavities under eaves in houses and farm buildings.

\section{Conclusions}

Through our searches we have found records for 16 attempts to ship House Sparrows to Australia, only nine of these shipments had birds that reached Australia alive. The acclimatisation societies intended to send large shipments but due to mortality on the voyage the founding populations were much smaller than intended but not impossibly small for the adaptable sparrow. An island population of House Sparrows has been successfully founded by only four individuals (Jensen et al. 2007) and the introduced populations to Australia rapidly increased from low numbers (Additional file 1: Table S5). Most of the birds shipped to Australia went to Melbourne in 1862-1863 with about 90-130 birds arriving alive over a 12 month period. The Melbourne population was founded by birds from England, Germany and also India, possibly leading to hybridisation between these two subspecies resulting in a population with a unique genetic composition. The findings that we have made from our intensive search of both primary and secondary sources, provide a picture of multiple introductions within a short space of time and a fairly rapid expansion across the whole eastern half of the Australian continent. This pattern of introduction and establishment should be detectable using molecular techniques and this work remains to be done. Nevertheless, our work 
demonstrates clearly that previous summaries of the introduction of this single species are inconsistent and erroneous and this does cast some doubt on the accuracy of the well-cited key references for bird introductions around the world. This suggests that such works should be used cautiously and ideally further work will take a similar approach that evaluates the accuracy of introduction histories for their target species and locations.

\section{Additional file}

Additional file 1. Supplementary tables: Table S1. Newspaper quotes, Table S2. Importation events, Table S3. Liberation events, Table S4 Range growth events, Table S5. Examples of population growth and Table S6. Citation consistency between major summaries of introduction history.

\section{Authors' contributions}

Both SCA and SCG contributed to data collection and the writing of the manuscript. SCA prepared tables and the figure. Both authors read and approved the final manuscript.

\section{Acknowledgements}

We would like to thank the Australian Museum for providing access to their research library and their copies of the acclimatisation records of New South Wales and Victoria. We would also like to thank David Peacock for his notes on the House Sparrow's introduction to South Australia.

\section{Availability of data and material}

All new data produced by our research is provided in our Additional file file 1: Tables S1, S2, S3, S4, S5 and S6. Any PDF's of newspaper articles that were used have been uploaded to figshare (https://dx.doi.org/10.6084/ m9.figshare.2061150) for accessibility.

\section{Competing interests}

The authors declare that they have no competing interests.

\section{Funding}

SCA was supported by Macquarie University Research Excellence Scholarships (No. 2013077). SCG was supported by an Australian Research Council Future Fellowship (FT130101253).

Received: 20 January 2016 Accepted: 2 May 2016 Published online: 18 May 2016

\section{References}

Anderson TR. Biology of the ubiquitous house sparrow: from genes to populations. New York: Oxford University Press; 2006.

Balmford R. Early introductions of birds to Victoria. Vic Nat. 1981;98:96-105.

Barrett G, Silcocks A, Barry S, Cunningham R, Poulter R. The new atlas of Australian Birds. Hawthorn East: Royal Australasian Ornithologist Union; 2003. p. 635-6.

Bennett G. The third annual report of the Acclimatisation Society of New South Wales, Sydney; 1864.

Bennett G. Papers on Acclimatisation by George Bennett, together with the 3rd-7th annual (1864-1868) report and proceedings of the Acclimatisation Society of New South Wales, Sydney; 1872.

Black J. Proceedings of the annual meeting of the Zoological and Acclimatisation Society of Victoria, Melbourne; 1872. p 25-28.

Blackburn TM, Lockwood JL, Cassey P. Avian invasions: the ecology and evolution of exotic birds. Oxford: Oxford University Press; 2009.
Blackburn TM, Prowse TAA, Lockwood JL, Cassey P. Passerine introductions to New Zealand support a positive effect of propagule pressure on establishment success. Biodivers Conserv. 2011a;20:2189-99.

Blackburn TM, Pyšek P, Bacher S, Carlton JT, Duncan RP, Jarošík V, Wilson JRU, Richardson DM. A proposed unified framework for biological invasions. Trends Ecol Evol. 2011b;26:333-9.

Blackburn TM, Prowse TAA, Lockwood JL, Cassey P. Propagule pressure as a driver of establishment success in deliberately introduced exotic species: fact or artefact? Biol Invasions. 2013;15:1459-69.

Blakers M, Davies SJJF, Reilly PN. The atlas of Australian Birds. Carlton: Melbourne University Press; 1984. p. 586-7.

Briskie JV, Mackintosh M. Hatching failure increases with severity of population bottlenecks in birds. PNAS. 2004;101:558-61.

Cassey P, Blackburn T, Sol D, Duncan R, Lockwood JL. Global patterns of introduction effort and establishment success in birds. Proc R Soc Lond B Biol Sci. 2004;271:S405-8.

Chisholm A. Introduced birds in Queensland. Emu. 1919;19:60-2.

Chisholm A. Birds introduced into New South Wales. Emu. 1926;25:276-9.

Condon HT. Notes on the birds of South Australia: occurrence distribution and taxonomy. S Aust Ornithol. 1951;8:26-68.

Congdon NM, Briskie JV. Effect of population bottlenecks on the egg morphology of introduced birds in New Zealand. Ibis. 2010;152:136-44.

Courcy C. Evolution of a zoo: a history of the Melbourne Zoological Gardens. Auburn: Quiddlers Press; 2003. p. 1-15.

Dlugosch KM, Parker IM. Founding events in species invasions: genetic variation, adaptive evolution, and the role of multiple introductions. Mol Ecol. 2008:17:431-49.

Duncan R, Blackburn T, Sol D. The ecology of bird introductions. Annu Rev Ecol Evol. 2003:34:71-98

Dunlap TR. Remaking the land: the acclimatization movement and anglo ideas of nature. J World Hist. 1997:8:303-19.

HALA. Atlas of living Australia; 2014. http://www.ala.org.au.

Hardy AD. Sky-larks and nightingales in Australia. Emu. 1928;27:300-1.

Higgins PJ, Peter JM, Cowling SJ. Handbook of Australian, New Zealand and Antarctic Birds: boatbill to starlings, vol. 7. Melbourne: Oxford University Press; 2006. p. 1070-88.

Jenkins C. The Noah's Ark Syndrome. Perth: The Zoological Gardens Board Western Australia; 1977. p. 73-95.

Jensen H, Bremset EM, Ringsby TH, Saether B-E. Multilocus heterozygosity and inbreeding depression in an insular house sparrow metapopulation. Mol Ecol. 2007;16:4066-78.

Johnston RF, Selander RK. House sparrows: rapid evolution of races in North America. Science. 1964;144:548-50.

Jones D. Exotic birds_-selected examples. In: Kitching R, Jones RE, editors. The ecology of exotic animals and plants: some Australian case histories. Brisbane: Wiley; 1986. p. 93-106.

Le Souef J. The introduction of sparrows into Victoria. Emu. 1958;58:264-6.

Leishman AJ. Introduced birds in the Botanic Gardens, Sydney. Aust Birds. 1997:31:1-11.

Lever C. Naturalized mammals of the world. London: Longman; 1985.

Lever C. Naturalized birds of the world. London: Longman Scientific \& Technical; 1987.

Lever C. They dined on eland. London: Quiller Press Ltd; 1992.

Lever C. Naturalised birds of the world. London: T\&AD Poyser; 2005. p. 204-18.

Liebl AL, Schrey AW, Andrew SC, Sheldon EL, Griffith SC. Invasion genetics: lessons from a ubiquitous bird, the house sparrow Passer domesticus. Curr Zool. 2015;61:465-76.

Littler FM. European birds in Tasmania. Emu. 1901;1:121-4.

Long JL. Introduced birds of the world: the worldwide history, distribution and influence of birds introduced to new environments. Sydney: Universe Books; 1981. p. 372-81.

Long JL. Introduced birds and mammals in Western Australia. Perth: Agriculture Protection Board of Western Australia; 1988. p. 13-4.

Moran EV, Alexander JM. Evolutionary responses to global change: lessons from invasive species. Ecol Lett. 2014. doi:10.1111/ele.12262.

Moulton MP, Cropper WP. A comparison of success rates of introduced passeriform birds in New Zealand, Australia and the United States. Peer J. 2014;2:e509.

Moulton MP, Cropper WP, Avery ML, Moulton LE. The earliest House Sparrow introductions to North America. Biol Invasions. 2010;12:2955-8. 
Moulton MP, Cropper WP, Avery ML. A reassessment of the role of propagule pressure in influencing fates of passerine introductions to New Zealand. Biodivers Conserv. 2011;20:607-23.

Moulton MP, Cropper WP, Avery ML. Historical records of passerine introductions to New Zealand fail to support the propagule pressure hypothesis. Biodivers Conserv. 2012a;21:297-307.

Moulton MP, Cropper WP, Moulton LE, Avery ML, Peacock D. A reassessment of historical records of avian introductions to Australia: no case for prop agule pressure. Biodivers Conserv. 2012b;21:155-74.

Musson CT. The House Sparrow in New South Wales. Sydney: Department of Agriculture; 1907. p. 1-17

Newsome A, Noble I. Ecological and physiological characters of invading species. In: Groves R, Burdon J, editors. Ecology of biological invasions: an Australian perspective. Cambridge: Cambridge University Press; 1986. p. $1-20$.

Parkin DT, Cole SR. Genetic differentiation and rates of evolution in some introduced populations of the House Sparrow, Passer domesticus in Australia and New Zealand. Heredity. 1985:54:15-23.

Pipek P, Pysek P, Blackburn TM. How the Yellowhammer became a Kiwi: the history of an alien bird invasion revealed. Neobiota. 2015:24:1-31.

Rolls EC. They all ran wild. Sydney: Angus \& Robertson LTD; 1969. p. 225-50.

Ryan CS. President's address: on European and other birds liberated in Victoria. Emu. 1906;5:110-9.

Sage B. Remarks on the racial status, history and distribution of the Tree Sparrow introduced into Australia. Emu. 1956;56:137-40.
Sage B. Remarks on the taxonomy, history and distribution of the House Sparrow introduced into Australia. Emu. 1957;67:349-52.

Sax DF, Stachowicz JJ, Brown JH, Bruno JF, Dawson MN, Gaines SD, Grosberg RK, Hastings A, Holt RD, Mayfield MM, O'Connor MI, Rice WR. Ecological and evolutionary insights from species invasions. Trends Ecol Evol. 2007;22:465-71.

Schrey AW, Grispo M, Awad M, Cook MB, McCoy ED, Mushinsky HR, Albayrak T, Bensch S, Burke T, Butler LK, Dor R, Fokidis HB, Jensen H, Imboma T, Kessler-Rios MM, Marzal A, Stewart IRK, Westerdahl H, Westneat DF, Zehtindjiev P, Martin LB. Broad-scale latitudinal patterns of genetic diversity among native European and introduced house sparrow (Passer domesticus) populations. Mol Ecol. 2011;20:1133-43.

Schrey AW, Liebl AL, Richards CL, Martin LB. Range expansion of house sparrows (Passer domesticus) in Kenya: evidence of genetic admixture and human-mediated dispersal. J Hered. 2014;105:60-9.

Sol D, Vilà M, Kühn I. The comparative analysis of historical alien introductions. Biol Invasions. 2008;10:1119-29.

Summers-Smith JD. The House Sparrow. London: Collins; 1963. p. 175-86. Sutton J. Acclimatization in South Australia. S Aust Ornithol. 1935;8:92-103. Tarr HE. The distribution of foreign birds in Australia. Emu. 1950;49:189-99.

Trove. National Library of Australia; 2015. http://trove.nla.gov.au/newspaper/ search?adv=y.

Whitney KD, Gabler CA. Rapid evolution in introduced species, "invasive traits" and recipient communities: challenges for predicting invasive potential. Divers Distrib. 2008;14:569-80.

\section{Submit your next manuscript to BioMed Central and we will help you at every step:}

- We accept pre-submission inquiries

- Our selector tool helps you to find the most relevant journal

- We provide round the clock customer support

- Convenient online submission

- Thorough peer review

- Inclusion in PubMed and all major indexing services

- Maximum visibility for your research

Submit your manuscript at www.biomedcentral.com/submit 